\title{
PERAN KESEPIAN DAN PENGUNGKAPAN DIRI ONLINE TERHADAP KECANDUAN INTERNET PADA REMAJA AKHIR
}

\author{
Mulia Dwi Ariani, Ratna Supradewi, dan Diany Ufieta Syafitri* \\ Fakultas Psikologi, Universitas Islam Sultan Agung, Jl. Kaligawe Raya KM. 4 Kota Semarang 50112 \\ Email : dianysyafitri@unissula.ac.id
}

\begin{abstract}
Abstrak
Penelitian ini bertujuan untuk mengetahui hubungan antara kesepian dan pengungkapan diri online dengan kecanduan internet pada remaja akhir. Variabel tergantung pada penelitian ini adalah kecanduan internet, variabel bebas penelitian ini adalah kesepian dan pengungkapan diri online. Penelitian ini menggunakan metode kuantitatif dan analisis dilakukan pada 100 remaja akhir. Metode pengambilan data dilakukan menggunakan tiga skala diantaranya skala kecanduan internet, skala kesepian, dan skala pengungkapan diri online. Skala kecanduan internet merupakan adaptasi dari Young's Internet Addiction Test (TIAT20) yang dikembangkan oleh Kimberly Young, skala terdiri antara 20 aitem. Skala kesepian merupakan adaptasi dari UCLA Loneliness Scale (Version 3) yang dikembangkan oleh Daniel W. Russel terdiri dari 20 aitem. Sedangkan skala pengungkapan diri dari online Revised Self-disclosure Scale yang dikembangkan Louis Leung yang kemudian diadaptasi oleh Ina Blau terdiri dari 9 aitem. Uji hipotesis pertama dalam penelitian ini menggunakan korelasi regresi ganda sedangkan untuk hipotesis kedua dan ketiga menggunakan analisis regresi parsial. Hasil uji hipotesis menunjukkan adanya hubungan positif yang signifikan dengan nilai korelasi $R=0,305$ dengan Flinier $=4,963$ dengan signifikansi 0,009 (dengan $p<0,05$ ). Analisis hipotesis kedua menunjukkan skor $r \times 1 y=0,126$ dengan $p=0,213$ (dengan $p>0,05$ ) yang menunjukkan bahawa tidak ada hubungan antara kesepian terhadap kecanduan internet. Analisis hipotesis' ketiga menunjukkan skor $r \times 2 y=0,261$ dengan $p=0,005$ (dengan $p=<0,01$ ). Hasil tersebut menunjukkan bahwa ada hubungan positif yang signifikan antara pengungkapan diri online dengan kecanduan internet.
\end{abstract}

Kata kunci : Kecanduan Internet, Kesepian, dan Pengungkapan Diri Online

\begin{abstract}
This study aims to determine the relationship between loneliness and online self-disclosure with internet addiction in adolescence teens. Variables depend on this research is internet addiction, independent variable of this research is loneliness and online self-disclosure. This study uses quantitative methods and analysis performed on 100 final adolescents. Methods of data retrieval were conducted using three scales such as internet addiction scale, loneliness scale, and online self-disclosure scale. The internet addiction scale is an adaptation of Young's Internet Addiction Test (TIAT20) developed by Kimberly Young, a scale consisting of 20 items. Loneliness scale is an adaptation of UCLA Loneliness Scale (Version 3) developed by Daniel W. Russel consists of 20 items. While the self-disclosure scale of the online Revised Self-disclosure Scale developed Louis Leung which is then adapted by Ina Blau consists of 9 items. The test of first hypothesis in this research used correlation of multiple regressions, the test of second and third hypothesis used partial regression analysis. The results of the first hypothesis test showed a significant positive relationship with the correlation value $R=0.305$ with Flinier $=4.963$ with $a$ significance of 0.009 (with $p<0.05$ ). Analysis of the second hypothesis showed a score of $r \times 1 y=0.126$ with $p=$ 0.213 (with $p>0.05$ ) which showed that there was no relationship between loneliness and internet addiction. The third hypothesis analysis shows the score of $r \times 2 y=0.261$ with $p=0.005$ (with $p=<0.01$ ). These results indicate that there is a significant positive relationship between online self-disclosure and internet addiction.
\end{abstract}

Keywords: Internet Addiction, Loneliness, and Online Self Disclosure 


\section{Pendahuluan}

Berkembangnya zaman mempengaruhi perkembangan teknologi yang semakin maju. Perkembangan teknologi internet semakin pesat dan semakin banyak peminatnya baik kalangan muda maupun kalangan orang tua, dan segala kategori ekonomi. Hal tersebut berpengaruh pada perilaku dan kehidupan masyarakat secara signifikan (Yofiyanto, 2008).

Berdasarkan survei Asosiasi Penyelenggara Jasa Internet Indonesia (APJII) pada 2016 menyatakan bahwa pengguna internet di Indonesia mencapai 132,7 juta pengguna. Pengguna internet antara usia 10-24 tahun mencapai 18,4\% atau sekitar 24,4 juta. Usia 25-34 tahun dengan presentase $24,4 \%$ atau 32,3 juta pengguna dan usia $35-44$ tahun mencapai $29,2 \%$ atau 38,7 juta. Pada usia $45-54$ tahun pengguna interent sebanyak $18 \%$ atau 23,8 juta dan siatas 55 tahun sebanyak $10 \%$ atau 13,2 juta pengguna (Isparmo, 2016).

We Are Sosial dan Hootsuite melakukan sebuah riset yang hasilnya menunjukkan bahwa pengguna internet di Indonesia pada 2017 mengalami peningkatan sebanyak 51\% dibandingkan dengan tahun sebelumnya. Indonesia saat ini menduduki peringkat pertama dalam pertumbuhan pengguna internet dimana pada peringkat kedua dan ketiga terdapat Filipina dan Meksiko dengan presentase masing-masing 27\% (Witoelar, 2017).

Berbagai macam informasi dan fasilitas inilah yang membuat individu mampu bertahan dalam kurun waktu yang lama didepan komputer atau smartphone. Keberagaman kemudahan penggunaan internet juga menjadi salah satu faktor pengguna mampu menghabiskan waktu dengan intenet di smartphone maupun komputer. Peningkatan dalam penggunaan internet saat ini sangat signifikan, sehingga dapat mengakibatkan munculnya masalah-masalah baru dengan istilah kecanduan internet atau internet addiction (Soetjipto, 2010).

Kecanduan internet mengacu pada penggunaan berlebihan jaringan internet yang dilakukan individu dan tidak bisa lepas dari penggunaan internet dalam kehidupan sehari-hari. Seseorang dapat dikatakan kecanduan internet apabila waktu penggunaan internet lebih dari tujuh jam dalam sehari, berarti lama penggunaan internet sama atau melebihi waktu tidur manusia dalam sehari (Hasanuddin, 2014).

Berdasarkan hasil studi yang dilakukan Universitas Hong Kong pada 2014 menyatakan bahwa $6 \%$ dari populasi manusia didunia mengalami kecanduan internet. Populasi manusia di dunia sekitar 7 miliyar, jadi sekitar 420 juta manusia di dunia mengalami kecanduan internet (Librianty, 2014). Di Indonesia sendiri berdasarkan hasil survei Alvara Research Center pada 1550 responden di enam kota besar di Indonesia menyatakan bahwa hampir 15\% pengguna internet di Indonesia mengalami kecanduan internet pada tahun 2013 (Hasanuddin, 2014).

Dampak negatif yang ditimbulkan akibat kecanduan internet juga semakin banyak dijumpai terutama bagi anak-anak dan remaja. Ancaman yang paling umum bagi individu yang mengalami kecanduan internet menurut Cromie (1999) adalah ketidakmampuan seseorang dalam mengatur emosi, menyebabkan individu menjadi tertutup dan acuh terhadap lingkungan sekitarnya yang akan mempengaruhi kehidupan sosialnya dengan teman bahkan keluarganya. Kecanduan internet juga dapat berdampak pada prestasi belajar hingga enakalan remaja yang memiliki kemungkinan menjerumuskan individu pada tindak kriminal, baik dunia nyata maupun dunia maya (Kem, 2005).

Penggunaan internet diseimbangi dengan bermunculannya aplikasi media sosial. Sosial media yang populer seperti Instagram, Facebook, Path, You Tube dan lain sebagainya menjadi salah satu faktor penggunaan internet yang dilakukan oleh individu termasuk para remaja. Zaman sekarang 
banyak individu termasuk remaja yang lebih sering mengunggah kehidupan sehari-harinya bahkan curhat dalam media sosial. Pengungkapan diri yang dilakukan secara online atau menggunakan jaringan internet ini bisa diterima lebih cepat ditimbang dengan cara offline (Suler, 2004).

Pengungkapan diri atau self disclosure merupakan bentuk komunikasi dan pemberian informasi mengenai pribadi atau diri sendiri, mengenai pikiran, perasaan, serta perilaku diri sendiri atau orang lain. Semakin berkembangnya perangkat komunikasi serta jaringan internet yang semakin maju mengakibatkan berubahnya cara komunikasi dari komunikasi tradisional hingga pengungkapan diri berbasis online. Menurut Barak dan Suler (2008) mengemukakan bahwa pengungkapan diri online atau self disclosure online ini hampir sama dengan pengungkapan diri offline dalam beberapa aspek (Blau, 2011).

Berdasarkan data pada 2010, menyatakan bahwa lebih dari 35 juta pengguna facebook memperbarui status mereka setiap harinya dan lebih dari 60 juta status diperbarui setiap hari. Selain itu terdapat lebih dari 3 milliar foto diunggah pada setiap bulannya. Pengunggahan kehidupan pribadinya tersebut berbagai alasan, mulai dari ingin sekedar berbagai, mendapat simpati, curhat, ingin populer, dan sebagainya (Kasali, 2011).

Selain itu terdapat faktor-faktor psikologis yang dapan mempengaruhi penggunaan internet pada remaja seperti perasaan kesepian yang timbul kapan dan dimana saja. Kesepian merupakan salah satu faktor yang dialami remaja. Kesepian merupakan kondisi ketidakseimbangan psikoemosional yang ditandai dengan perasaan kosong atau merasa hampa akibat kurangnya ikatan dengan orang lain. Penggunaan internet menjadi salah satu coping dari kesepian yang sedang dihadapi.

Para pengguna internet sejatinya mendapat berbagai manfaat dari adanya internet. Dengan adanya internet, individu terutama remaja dapat mendapatkan jaringan pertemenan yang lebih luas (Hasanuddin, 2014). Berbagai macam informasi dan fasilitas inilah yang membuat individu mampu bertahan dalam kurun waktu yang lama didepan komputer atau smartphone. Peningkatan dalam penggunaan internet saat ini sangat signifikan, sehingga dapat mengakibatkan munculnya masalahmasalah baru dengan instilah kecanduan internet atau internet addiction (Soetjipto, 2010).

Remaja sejatinya merupakan masa-masa pencarian jati diri yang memerlukan hubungan sosial yang luas. Remaja merupakan masa transisi dari masa anak-anak menuju masa dewasa. Usia remaja umumnya berada diantara usia 12 tahun sampai 21 tahun (Harlock, 2002). Sebanyak 27\% dari seluruh penduduk Indonesia yang berjumlah lebih dari 262 juta jiwa masuk dalam usia remaja. Dapat dikatakan sebanyak lebih dari 69 juta masuk dalam usia remaja (Setiawan, 2017). Hubungan sosial saat ini bisa ditemukan dengan berbagai cara termasuk dengan penggunaan internet. Faktor penggunaan internet pada remaja semakin meningkat dengan semakin mudahnya penggunaan internet dimana dan kapanpun remaja berada. Ditambah dengan adanya komunikasi online, media sosial, penggunaan games dan faktor psikologis lainnya yang menjadikan intensitas penggunaan internet meningkat dan mempengaruhi perilaku manusia termasuk remaja (Dariyo \& Widiyanto, 2013).

Komunikasi online saat ini menjadi sebuah kebutuhan. Hal tersebut juga menjadi media sosialisasi yang lebih luas sehingga remaja dapat berkomunikasi dengan mudah dimana dan kapanpun mereka berada. Penggunaan komunikasi secara online, remaja akan lebih mudah mengembangkan kehidupan sosial. Komunikasi online juga bisa menjadi sarana yang efektif dan efisien mengembangkan pertemanan tanpa dibatasi oleh agama, suku, sosial ekonomi, budaya dan sebagainya (Dariyo \& Widiyanto, 2013). Sehingga dengan komunikasi yang berbasis online ini menjadikan penggunaan internet semakin intensif. 
Berbagai aplikasi mobile bisa didapat secara mudah dengan cara pengunduhan di Google Play atau AppStore. Penelitian yang dilakukan oleh com.Score pada Januari 2017 terhadap sepuluh aplikasi dari perangkat mobile di Indonesia. Sepuluh aplikasi beserta urutannya tersebut adalah Google Play, Whatsapp, You Tube, BBM, Google Search, Gmail, Line, Instagram, Facebook, Google Maps (Pratama, 2017).

Penggunaan internet semakin intensif dengan adanya media sosial yang semakin banyak dan mudah untuk didapatkan. Sosial media yang populer seperti Instagram, Facebook, Path, You Tube dan lain sebagainya menjadi salah satu faktor penggunaan internet yang dilakukan oleh individu termasuk para remaja. Berdasarkan hasil survei yang dilakukan oleh Asosiasi Penyelenggara Jasa Internet Indonesia (APJII) pada 2016, media sosial yang paling sering dikunjungi adalah facebook dengan persentase $54 \%$ atau sebesar 71,6 juta pengguna. Selanjutnya terdapat instagram dengan presentase $15 \%$ atau sebesar 19,9 juta pengguna (Isparmo, 2016).

Kecanduan internet tersebut memiliki dampak yang sangat luas dan disebabkan oleh banyak faktor. Remaja yang sedang masa pencarian jadi diri pun menjadi dampak dari perkembangan teknologi. Kebiasaan remaja untuk mengunggah kehidupan pribadi secara rutin dan menghilangkan rasa sepi dengan cara penggunaan internet menjadi fenomena saat ini. Berdasarkan fenomena tersebut, memunculkan pertanyaan peneliti apakah ada hubungan antara kesepian dan pengungkapan diri terhadap kecanduan internet pada remaja.

\section{Tinjauan Literatur}

\section{Kencanduan Internet}

Istilah internet addiction atau kecanduan internet pertama kali dikemukakan oleh Kimberly Young pada tahun 1996. Meski sebelumnya banyak ahli psikologi yang telah mengkaji mengenai interaksi antara manusia dengan komputer. Kemudian munculah kontroversi dengan penggunaan kata kecanduan yang dilakukan oleh Young (Frangos, Frangos, \& Sotiropoluos, 2012). Meskipun demikian pada prinsipnya, istilah kecanduan tersebut mengacu pada ketergantungan individu pada zat-zat yang merugikan tubuh. (Soetjipto, 2010). Kecanduan internet dapat diklasifikasikan berdasarkan intensitas penggunaannya (Pratarelli, Browne, \& Johnson, 1999), yaitu a) Gangguan pada perilaku yang berupa penggunaan internet secara berlebihan b) Penggunaan internet sesuai dan secara fungsional, produktif, dan bermakna. c) Penggunaan internet guna mendapat kepuasan seksual dan atau mendapatkan keuntungan sosial. Widyanto dan Mark menyatakan bahwa terdapat tiga dimensi untuk menggolongkan individu termasuk kecanduan internet atau tidak (Widyanto \& Mark, 2010), berikut dimensi-dimensi tersebut a) Konflik Psikologis/ Emosional. Konflik psikologis berkaitan dengan konsep secara online kehidupan sosial individu, dan pengorbanan waktu dengan teman serta keluarga untuk kehidupan online. b) Masalah Manajemen Waktu berkaitan dengan banyaknya waktu yang digunakan untuk online daripada sebelumnya atau untuk produktivitas dalam berkarya. c) Modifikasi Perasaan berkaitan dengan perasaan takut ketika kehilangan internet, munculnya rasa bosan saat sedang offline, hingga hilangnya waktu istirahat dikarenakan online secara terus menerus.

\section{Kesepian}

Kesepian merupakan kondisi dimana psiko-emosional individu tidak seimbang dengan munculnya rasa hampa dan kosong dalam diri dikarenakan ikatan dengan orang lain yang kurang. 
Individu yang merasa kesepian saat bersosialisasi dengan lingkungannya akan merasa kurang bahagia, kurang puas, pesimis, dan kurang bersemangat (Taylor, Peplau, \& Sears, 2001). Terdapat tiga poin penting mengenai kesepian (Peplau \& Perlman, 1982) antara lain a) Kesepian adalah hasil dari berkurangnya hubungan sosial b) Kesepian adalah pengalam yang bersifat subjektif yang bergantung pada persepsi individu terhadap situasi yang dihadapi c) Kesepian adalah pengalaman yang menyedihkan serta tidak menyenangkan. Terdapat beberapa aspek yang mempengaruhi kesepian (Russell, 1996)yaitu a) Kepribadian Karakteristik seseorang atau kepribadian seseorang yang muncul berdasarkan sistem-sistem psikofisik akan menentukan bagaimana individu tersebut berperilaku dan berpikir mengenai lingkungan sekitar. Sehingga seseorang yang merasa kesepian dapat dilihat dari perilaku dan perasaannya sehari-hari. b) Kepatutan Sosial seseorang tersebut menginginkan adanya penerimaan yang berujung pada keinginan untuk mendapatkan pengakuan dari lingkungan sekitarnya. c) Depresi merupkan salah satu jenis tekanan yang berasal dari dalam diri yang dapat mengakibatkan adanya perasaan tidak berdaya, hilangya harapan yang diikuti perasaan sedih, hilangnya rasa gembira hingga minat terhadap sesuatu, energi yang berkurang sehingga merasa mudah lelah dan mengakibatkan berkurangnya aktivitas.

\section{Pengungkapan Diri}

Pengertian pengungkapan diri atau self disclosure merupakan bentuk komunikasi dan pemberian informasi mengenai pribadi atau diri sendiri, mengenai pikiran, perasaan, serta perilaku diri sendiri atau orang lain. Pengungkapan diri ini berkaitan dengan informasi yang biasanya disembunyikan serta melibatkan orang lain (Devito, 2011). pengungkapan diri ini bisa dalam berbagai bentuk seperti perilaku, perasaan, keinginan, sikap, atau dalam bentuk ide yang sesuai dan terdapat padad orang yang bersangkutan (Dayakisni \& Hudaniah, 2006). Pengungkapan diri dibedakan menjadi lima bagian dimensi (Leung, 2012), yaitu a) Ukuran Pengungkapan Diri (Amount) Ukuran pengungkapan diri ini dilihat dari frekuensi individu melakukan pengungkapan diri dan durasi pesan-pesan yang memiliki sifat mengungkapkan dirinya, atau waktu yang dibutuhkan untuk mengungkapkan pengungkapan tersebut. b) Valensi Pengungkapan Diri (Valence Self Disclosure) Valensi pengungkapan diri yang dimaksud adalah positif atau negatif pengungkapan diri tersebut. c) Kecermatan dan Kejujuran Pengungkapan Diri (Accuracy and Honesty) Kecermatan dan ketepatan individu dalam pengungkapan diri akan dibatasi dengan sejauh mana individu mengenal diri sendiri. d) Tujuan dan Maksud Pengungkapan Diri (Intention) Individu memiliki tujuan dan maksud tertentu dalam pengungkapan dirinya. e) Keakraban (Intimacy) sejauh mana pengungkapan diri dapat ditentukan dengan tingkat keakraban dengan lawan komunikasi. Semakin akrab individu dengan lawan bicara akan semakin dalam dan luas pengungkapan dirinya. Menurut Blau merupakan tiga dari lima dimensi tersebut kecuali ukuran pengungkapan diri dan valensi pengungkapan diri. Hal tersebut dikarenakan dua dimensi tersebut kurang relevan dalam mengukur pengungkapan diri secara online (Blau, 2011).

\section{Remaja}

Remaja adalah usia peralihan dari masa anak-anak menjadi masa dewasa, dimana anakanak mulai matang secara secara seksual sampai usia matang secara hukum (Harlock, 2002). Remaja merupakan individu yang ada diusia antara 12-21 tahun yang telah melalui masa peralihan dengan 
pembagian usia 12-15 tahun merupakan remaja awal, 15-18 tahun merupakan remaja pertengahan, dan 18-21 tahun merupakan masa remaja akhir (Monks, 1999)

\section{Metode}

Penelitian ini menggunakan metode kuantitatif dengan teknik analisis dalam penelitian ini menggunakan teknik analisis regresi dua prediktor dan korelasi parsial. Analisa data akan menggunakan bantuan program SPSS 16 for windows. Analisis regresi dua prediktor termasuk analisis regresi ganda yang memiliki tujuan untuk mengetahui tinggi rendahnya nilai dari suatu variabel tergantung berdasarkan dua variabel bebas. Sedangkan metode korelasi parsial dilakukan untuk mengetahui hubungan atau pengaruh antara variabel bebas dan variabel tergantung dimana terdapat satu variabel bebas yang dikontrol.

\section{Variabel dan Instrumen Penelitian}

Penelitian ini mengkaji tiga variabel yaitu kecanduan interent, kesepian dan pengungkapan diri online. Variabel tergantung dalam penelitian ini adalah kecanduan internet, sedangkan variabel bebas penelitian ini adalah kesepian dan pengungkpan diri online. Pada penelitian ini skala yang digunakan merupakan skala adaptasi yang menggunakan Bahasa Inggris sehingga perlu dialihbahasakan dalam Bahasa Indonesia. Berikut adalah penjelasan tahap-tahap yang perlu dilakukan dalam melakukan alih bahasa pada skala yang digunakan dalam penelitian ini (Sousa \& Rojjanasrirat, 2011) :

1. Proses menterjemahkan skala dari bahasa asli menjadi bahasa target

2. Proses pembandingan dua penerjemah

3. Proses penilaian redaksional yang dilakukan oleh ahli (profesional judgement)

4. Proses penilaian redaksional yang dilakukan oleh beberapa orang yang memiliki karakteristik yang sama dengan sampel penelitian

Skala kecanduan internet dalam penelitian ini menggunakan Young's Internet Addiction Test (TIAT20) yang dikembangkan oleh Kimberly Young dan memiliki jumlah aitem sebanyak 20. Skala kecanduan internet ini menurut Widyanto terdapat tiga dimensi, yaitu konflik psikologis emosional, masalah manajemen waktu, dan modifikasi perasaan (Widyanto \& Mark, 2010).

Tabel 1. Blue Print Skala Kecanduan Internet

\begin{tabular}{|c|c|c|c|}
\hline No & Dimensi & Nomor Aitem & Jumlah \\
\hline 1. & $\begin{array}{l}\text { Konflik Psikologis/ } \\
\text { Emosional }\end{array}$ & $\begin{array}{c}3,5,8,9,10,11 \\
17,18,19\end{array}$ & 9 \\
\hline 2. & $\begin{array}{l}\text { Masalah Menejemen } \\
\text { Waktu }\end{array}$ & $1,2,6,7,16$ & 5 \\
\hline 3. & Modifikasi Perasaan & $4,12,13,14,15,20$ & 6 \\
\hline \multicolumn{3}{|c|}{ Jumla } & 20 \\
\hline
\end{tabular}

Skala kesepian diperoleh dari UCLA Loneliness Scale Version 3 yang dikembangkan oleh Russel dan memiliki jumlah aitem sebanyak 20. Skala kesepian ini memiliki tiga aspek, yaitu kepribadian, kepatutan sosial, dan depresi (Russell, 1996). 
Tabel 2.Blue Print Skala Kesepian

\begin{tabular}{ccccc}
\hline \multirow{2}{*}{ No } & \multirow{2}{*}{ Aspek } & \multicolumn{2}{c}{ Nomor Aitem } & \multirow{2}{*}{ Jumlah } \\
\cline { 3 - 4 } & & $4,13,17$ & unfavorable & \\
\hline 1. & Kepribadian & $7,8,18$ & $1,5,10,15,19$ & 5 \\
2. & Keinginan Sosial & $2,3,11,12,14$ & 16,20 & 7 \\
3. & Depresi & $\mathbf{1 1}$ & $\mathbf{9}$ & $\mathbf{2 0}$ \\
\hline & Jumlah & &
\end{tabular}

Sedangkan skala pengungkapan diri diadaptasi dari Revised Self-disclosure Scale yang dikembangkan oleh Leung. Namun pada skala pengungkapan diri online, peneliti menggunakan alat ukur Blau yang dikembangkan oleh Leung (Leung, 2012).

Tabel 3 .Blue Print Skala Pengungkapan Diri Online

\begin{tabular}{clcc}
\hline No & \multicolumn{1}{c}{ Dimensi } & Nomor Aitem & Jumlah \\
\hline 1. & Kedalaman atau intimasi & $6,9,3$ & 3 \\
2. & Akurasi & $2,4,8$ & 3 \\
3. & Niat & $1,5,7$ & 3 \\
\hline \multicolumn{3}{r}{} \\
\hline
\end{tabular}

\section{Subjek Penelitian}

Pengabilan sempel pada penelitian menggunakan Accidental sampling yaitu teknik yang mana siapa saja yang secara kebetulan bertemu dengan peneliti yang dapat digunakan sebagai sampel, dan orang yang kebetulan ditemui sesuai dengan sumber data (Hadi, 2000). Sempel di ambil dari mahasiswa universitas islam sultan agung semarang sebajak 100 mahasiswa.

Hasil

Peneliti melakukan uji reliabilitias pada skala kecanduan internet, skala kesepian dan skala pengungkapan diri online. Hal tersebut dilakukan untuk mengetahui reliabilitas skala apabila dilakukan penelitian di Indonesia. Uji coba dilakukan terhadap 102 mahasiswa Universitas Islam Sultan Agung. Setelah dilakukan uji reliabilitas maka diperoleh hasil yaitu skala kecanduan internet dengan nilai alpha cronbach 0,880 . Skala kesepian dengan nilai alpha cronbach 0,824 , dalam skala kesepian ini terdapat dua aitem yang memiliki reliabilitas dibawah 0,25 . Sedangkan untuk skala pengungkapan diri online memiliki nilai alpha cronbach 0,745 .

Berdasarkan dari uji korelasi yang telah dilakukan menggunakan teknik analisis regresi menunjukkan bahwa diperoleh $\mathrm{R}=0,305$ dan $\mathrm{F}_{\text {linier }}=4,963$ dengan signifikansi 0,009 (dengan $\mathrm{p}<0,05$ ). Hal tersebut menunjukkan bahwa adanya hubungan antara kesepian dan pengungkapan diri online terhadap kecanduan internet pada remaja akhir.

Berdasarkan uji korelasi parsial yang telah dilakukan pada penelitian ini antara variabel kesepian dan kecanduan internet dengan melakukan kontrol pada variabel pengungkapan diri online maka siperoleh $r_{x 1 y}=0,226$ dengan $p=0,213$ (dengan $p>0,05$ ). Hasil tersebut menunjukkan bahwa ada hubungan negatif yang tidak signifikan antara kesepian terhadap kecanduan internet. Sedangkan untuk uji korelasi parsial yang dilakukan antara pengungkapan diri online dengan kecanduan internet maka diperoleh $r_{x 2 y}=0,216$ dengan $p=0,005$ (dengan $p=<0,01$ ). Hal tersebut menunjukkan bahwa adanya hubungan positif yang signifikan antara pengungkapan diri online dengan kecanduan internet. 


\section{Pembahasan}

Penelitian ini dilakukan pada 100 mahasiswa yang terdiri dari 67 perempuan dan 33 laki-laki. Penelitian ini dilakukan guna mengetahui hubungan antara kesepian dan pengungkapan diri online dengan kecanduan internet. Berdasarkan hasil dari hipotesis pertama yaitu adanya hubungan antara kesepian dan pengungkapan diri online dengan kecanduan internet, perolehan nilai $R=0,305$ dan $F_{\text {hitung }}$ $=4,963$ dengan signifikansi $0,092(p<0,05)$. Hal ini berarti kesepian dan pengungkapan diri online memberikan sumbangan efektif sebesar 9,3\% kepada kecanduan internet dan 90,7 \% dijelaskan oleh faktor-faktor yang lain. Berdasarkan hasil tersebut menunjukkan bahwa hipotesis pertama pada penelitian ini dapat diterima.

Pada uji korelasi hipotesis kedua dilakukan terhadap variabel kesepian terhadap kecanduan internet dengan dikontrolnya variabel pengungkapan diri online. Dari uji tersebut diperoleh nilai $r_{x 1 y}=$ 0,126 dengan $p=0,213$ ( $p>0,05$ ). Data tersebut menunjukkan bahwa adanya hubungan negatif yang tidak signifikan antara kesepian terhadap kecanduan internet. Hal ini menunjukkan bahwa hipotesis kedua pada penelitian ini tidak diterima atau ditolak karena hasil penelitian menunjukkan bahwa tidak ada hubungan antara kesepian terhapat kecanduan internet.

Uji hipotesis ketiga yang dilakukan pada variabel pengungkapan diri online terhadap kecanduan internet dengan mengontrol variabel kesepian. Pada uji hipotesis ketiga ini hasil yang diperoleh adalah $r_{x 2 y}=0,281$ dengan nilai signifikansi $0,005(p<0,01)$. Hasil ini menunjukkan hipotesis ketiga yang diajukan oleh peneliti dapat diterima.

Berdasarkan data yang telah didapatkan berdasarkan penelitian yang telah dilakukan, hasil hasil analisis data kecanduan internet menunjukkan bahwa masuk dalam kategori rendah dengan skor mean empirik sebesar 48,91. Pada hasil analisis data kesepian menunjukkan kategori rendah dengan mean empirik 37,43. Sedangkan pada hasil analisis data pengungkapan diri online menunjukkan kategori sedang dengan mean empirik sebesar 26,05.

Kecanduan internet sendiri dipengaruhi oleh beberapa faktor yaitu jenis kelamin, kondisi psikologis, kondisi sosial ekonomi, dan tujuan serta waktu penggunaan internet (Frangos, Frangos, \& Sotiropoluos, 2012). Rasa kesepian yang menjadi salah satu dari faktor psikologis sering diakibatkan oleh berkurang atau hilangnya hubungan sosial dengan orang lain sehingga individu akan melampiaskan rasa sepi tersebut dengan penggunaan internet yang semakin tinggi seperti bermain games, penggunaan media sosial, belanja online, atau mencari berbagai informasi dan sebagainya (Young, Pistner, O'Mara, \& Buchanan, 1999).

Rendahnya tingkat kesepian pada subjek penelitian yang merupakan remaja akhir dan sebagai mahasiswa yang memiliki tugas-tugas kuliah, dan pandai bergaul dalam membina hubungan dengan orang lain. Meskipun diantaranya terdapat subjek yang kurang memiliki tugas kuliah ataupun kurang pergaulan, namun mereka tidak merasakan kesepian yang melandanya atau justru menikmatinya. Seperti yang dijabarkan oleh Radikun mengenai kesepian yaitu apabila seseorang merasa menderita dan merasa dirinya kurang dalam bergaul baik secara kualitas maupun kuantitas dalam membina hubungan dengan orang lain maka disebut kesepian. Namun apabila individu tidak mempermasalahkan hal tersebut atau bahkan menikmatinya maka hal tersebut bukanlah orang yang kesepian. 


\section{Kesimpulan}

Berdasarkan penelitian yang telah dilakukan dan penjabaran dalam pembahasan, maka dapat disimpulkan bahwa hipotesis pertama pada penelitian ini dapat diterima yaitu kesepian dan pengungkapan diri online memiliki peran yang signifikan terhadap kecanduan internet pada remaja akhir. Namun, disisi lain hipotesis kedua pada penelitian ini tidak diterima. Hal tersebut ditunjukkan dengan hasil penelitian yang menyatakan bahwa tidak ada hubungan antara kesepian dengan kecanduan internet. Sedangkan hipotesis ketiga pada penelitian ini diterima. Hal ini didukung dengan hasil penelitian yang mengungkapkan bahwa ada hubungan antara pengungkapan diri online dengan kecanduan internet. Kesepian serta pengungkapan diri online menyumbang sebesar 9,3\% terhadap kecanduan internet.

\section{Kelemahan Penelitian}

1. Jumlah subjek penelitian yang kurang sehingga kurang representatif dapat menggambarkan keseluruhan subjek secara universal atau umum.

2. Subjek pada saat dilakukannya uji coba terlalu sedikit sehingga terdapat aitem yang gugur pada skala adaptasi UCLA Loneliness Scale (Version 3) guna menggambarkan tingkat kesepian.

3. Tidak melakukan backward translation karena keterbatasan waktu penelitian.

\section{Saran}

1. Remaja

a. Remaja diharapkan dapat memanfaatkan internet sesuai kebutuhan dan memperbanyak hubungan didunia nyata daripada dunia maya.

b. Mempertahankan tingkat kesepian yang rendah sehingga mengurangi tingkat kecanduan internet.

c. Memperbanyak membuka diri terhadap orang terdekat daripada melakukan pengungkapan diri secara online.

2. Peneliti Selanjutnya

a. Peneliti selanjutnya diharapkan melakukan studi pendahuluan dengan subjek yang lebih representatif guna mendapatkan permasalahan yang lebih jelas.

b. Peneliti selanjutnya diharapkan mampu meneliti menggunakan faktor-faktor lain atau variabel-variabel lain yang dapat menggambarkan mengenai kecanduan internet.

\section{DAFTAR PUSTAKA}

Blau, I. (2011). Application use, online relationship types, self disclosure, and internet abuse among children and youth : implications for education and internet safety programs. Journal Educational Computing Research, 45(1) 1-22.

Hasanuddin. (2014, Mei 3). Internet adalah candu, fenomena pengguna internet indonesia. Diambil kembali dari Alvara Strategic: http://alvara-strategic.com/internet-adalah-candu-fenomenapengguna-internet-indonesia/ 
Isparmo. (2016, November 21). Data statistik pengguna internet indonesia tahun 2016. Diambil kembali dari Pembicara Internet Marketing SEO: http://isparmo.web.id/2016/11/21datastatistik-pengguna-internet-indonesia-2016/

Kasali, R. (2011). Cracking zone : bagaimana memerakan perubahan di abad ke-21 \& keluar dari perangkap confort zone. Jakarta: PT. Gramedia Pustaka Utama.

Kem, L. (2005). Gamer addiction : a threat to student succes! What advisors need to know. NACADA Clearinghouse of Academic Advising.

Leung, L. (2012). Loneliness, self-disclosure, and ICQ ("I Seek You") Use. Cyberpsychology \& Behavior, 5(3), 1-11.

Librianty, A. (2014, Desember 26). 420 juta orang di dunia kecanduan internet. Diambil kembali dari Liputan6: http://m.liputan6.cim/tekno/read/2150652/420-juta-orang-di-dunia-kecanduaninternet

Russell, D. W. (1996). UCLA Loneliness scale (version 3): reliability, validity, and factor structure. Journal of personality assessment 66(1) 20-40.

Soetjipto, H. P. (2010). Pengujian validitas konstruk kriteria kecanduan internet. Jurnal Psikologi, 32(2), 3-6.

Sousa, V. D., \& Rojjanasrirat, W. (2011). Translation, adaptation and validation of instruments or scales for use in cross-cultural health care research: A clear and user-friendly guideline. Journal of Evaluation in Clinical, 268-274.

Suler, J. (2004). The Online Disinhibition Effect. CyberPsychology \& Behavior, 323.

Widyanto, L., \& Mark, G. (2010). A Psychometric Comparison of the Internet Addiction Test,the Internet-Related Problem Scale, and Self-Diagnosis. Cyberpsychology, Behavior, and Social Networking, 00(00), 1-10.

Witoelar, W. (2017, Mei 22). Pertumbuhan Pengguna Internet, Indonesia Nomor 1 di Dunia. Diambil kembali dari Databoks: http://databoks.katadata.co.id/datapublish/2017/05/22/pertumbuhanpengguna-internet-indonesia-nomor-1-di-dunia

Yofiyanto, E. (2008). Internet Bagian Dari Gaya Hidup Modern. 